\title{
Antimicrobial essential oil of Origanum boissieri Ietswaart
}

\author{
Gökalp İSCAN 1 * (D), Betül DEMİRCi் 1 (D), Yavuz Bülent KÖSE 2 (D) \\ 1 Department of Pharmacognosy, Faculty of Pharmacy, Anadolu University, Eskisehir, 26470 Turkey. \\ 2 Department of Pharmaceutical Botany, Faculty of Pharmacy, Anadolu University, Eskisehir, 26470 Turkey. \\ * Corresponding Author. E-mail: giscan@anadolu.edu.tr (G.I..); Tel. +90-222-335 0580.
}

Received: 23 September 2019 / Revised: 05 December 2019 / Accepted: 03 February 2020

\begin{abstract}
Apart from being a popular spice, Origanum species is very important taxa as an herbal medicine for their several pharmacological activities. Essential oils of Origanum species bearing phenolic monoterpenoids such as carvacrol and thymol demonstrated strong antimicrobial properties. In the present study hydrodistilled essential oil of endemic species Origanum boissieri Ietswaart were analysed by GC and GC/MS techniques simultaneously. Thirty compounds representing $95.1 \%$ of the total oil were identified. Carvacrol (39\%) and $p$-cymene (32\%) were detected as the main components of the oil. Total methanol extract and essential oil of the flowering aerial parts of the plant with the carvacrol and $p$-cymene were screened for its antibacterial and anticandidal properties by using microdilution broth assay. Bacillus cereus, Bacillus subtilis, Staphylococcus aureus, Staphlylococcus epidermidis and Listeria monocytogenes were strongly inhibited by the oil between the concentrations of $15,6-62.5 \mu \mathrm{g} / \mathrm{mL}$. O. boissieri extract and the oil showed moderate effects against all tested Candida strains having MIC values of $125-1000 \mu \mathrm{g} / \mathrm{mL}$.
\end{abstract}

KEYWORDS: Origanum boissieri, essential oil, MIC, antimicrobial, GC/MS.

\section{INTRODUCTION}

Origanum L. (Lamiaceae) is an important medicinal and aromatic plant genus comprises of 42 species and 49 taxa divided into ten sections, mainly found in the Mediterranean region [1, 2]. In Turkey, Origanum species known as "Kekik" and represented by 23 species and 31 taxa of which 21 are endemic. Five of them have a great economic importance; Origanum onites, O. majorana (syn. O. dubium), O. vulgare subsp. hirtum, O. minutiflorum and O. syriacum var. bevanii [3-5].

Genus Origanum is very important herbal medicine for its several bioactivities such as antioxidant, antiviral, antimicrobial, antiparasitic, analgesic, hypotensive, antimutagenic, antihyperglycaemic and anticancer [4, 6-11].

Some members of Origanum taxa are extensively used around the world as a spice with the name of "oregano". Besides being a popular spice, many studies have been reported that Origanum essential oils (OEo) are important products for pharmaceutical purposes. OEo contain several phenolic monoterpenes and some sesquiterpenes that are known to demonstrate strong antimicrobial activity. The main compounds of them are generally carvacrol, thymol, $p$-cymene and $\gamma$-terpinene. According to chemo-types, proportions of these compounds in the same species vary between the specimens [12-15].

The major compounds of the oil carvacrol and thymol have been classified as GRAS and the antimicrobial effects of them have been studied many times by different authors, which is possess remarkable inhibition effects on pathogenic bacteria and fungi [16-25].

The endemic species Origanum boissieri Ietswaart belongs to Amaracus (Gleditsch) Bentham section. It is characterized by 1 or 2-lipped sepals without teeth, purplish bracts, and saccate corollas. The combination of a saccate corolla and distinctly toothed upper and lower calyx lips distinguishes this species from the other three Turkish species of Sect. Amaracus [26]. There was only one work on O. boissieri essential oil studied previously by our group [27].

In this study, chemical composition of hydrodistilled essential oil of $O$. boissieri was determined by GCFID and GC/MS techniques simultaneously. Essential oil and the crude methanol extract of the aerial parts of $O$. boissieri have been evaluated for their antibacterial and anticandidal effects comparing with the major compounds and standard antimicrobials for the first time here.

How to cite this article: İşcan G, Demirci B, Köse YB. Antimicrobial essential oil of Origanum boissieri letswaart. J Res Pharm. 2020; 24(2): 233239. 


\section{RESULTS AND DISCUSSION}

Chemical composition of hydrodistilled essential oil of flowering aerial parts $O$. boissieri were determined by GC-FID and GC/MS techniques simultaneously (Figure 1). Oxygenated monoterpenes (49.3\%), monoterpene hydrocarbons $(36.5 \%)$ and sesquiterpene hydrocarbons $(4.6 \%)$ were the main groups among the chemicals in the oil (Table 1). Thirty components were characterized, representing $95.1 \%$ of the total components detected. The main constituents were identified as carvacrol (39\%) and $p$-cymene (32\%). Similar results were reported in previous study, which were determined $p$-cymene $(43 \%)$ and carvacrol $(18 \%)$ as main components of the O. boissieri oil [27].

Table 1. The chemical composition of the essential oil of O. boissieri.

\begin{tabular}{|c|c|c|c|c|}
\hline $\mathbf{R R I}^{\mathbf{a}}$ & $\begin{array}{l}\text { Main Group } \\
\text { Code }^{\text {b }}\end{array}$ & Compound & $(\%)^{c}$ & $\mathrm{IM}^{\mathrm{d}}$ \\
\hline 1032 & 1 & a-Pinene & 0.7 & $\mathrm{tR}, \mathrm{MS}$ \\
\hline 1035 & 1 & a-Thujene & 0.9 & MS \\
\hline 1076 & 1 & Camphene & 1.1 & $\mathrm{tR}, \mathrm{MS}$ \\
\hline 1118 & 1 & $\beta$-Pinene & 0.2 & $\mathrm{tR}, \mathrm{MS}$ \\
\hline 1188 & 1 & a-Terpinene & 0.9 & $\mathrm{tR}, \mathrm{MS}$ \\
\hline 1203 & 1 & Limonene & 0.3 & $\mathrm{tR}, \mathrm{MS}$ \\
\hline 1218 & 1 & $\beta$-Phellandrene & 0.3 & $\mathrm{tR}, \mathrm{MS}$ \\
\hline 1265 & 5 & 3-Octanone & 0.3 & MS \\
\hline 1280 & 1 & $p$-Cymene & 32.1 & $t R, M S$ \\
\hline 1393 & 5 & 3-Octanol & 0.2 & $\mathrm{tR}, \mathrm{MS}$ \\
\hline 1451 & 2 & $\beta$-Thujone & 0.5 & MS \\
\hline 1474 & 2 & trans-Sabinene hydrate & 1.5 & MS \\
\hline 1556 & 2 & cis-Sabinene hydrate & 0.5 & MS \\
\hline 1611 & 2 & Terpinen-4-ol & 1.4 & $\mathrm{tR}, \mathrm{MS}$ \\
\hline 1612 & 3 & $\beta$-Caryophyllene & 3.0 & $\mathrm{tR}, \mathrm{MS}$ \\
\hline 1624 & 2 & trans-Dihydrocarvone & 0.5 & MS \\
\hline 1645 & 2 & cis-Isodihydrocarvone & 0.3 & MS \\
\hline 1662 & 2 & Pulegone & 0.6 & $\mathrm{tR}, \mathrm{MS}$ \\
\hline 1687 & 3 & a-Humulene & 0.4 & $\mathrm{tR}, \mathrm{MS}$ \\
\hline 1706 & 2 & a-Terpineol & $\operatorname{Tre}$ & $\mathrm{tR}, \mathrm{MS}$ \\
\hline 1719 & 2 & Borneol & 3.8 & $\mathrm{tR}, \mathrm{MS}$ \\
\hline 1741 & 3 & $\beta$-Bisabolene & 1.2 & MS \\
\hline 1864 & 2 & p-Cymen-8-ol & 0.4 & $\mathrm{tR}, \mathrm{MS}$ \\
\hline 1940 & 5 & 4-Isopropyl salicylaldehyde & 0.8 & MS \\
\hline 2008 & 4 & Caryophyllene oxide & 2.5 & $\mathrm{tR}, \mathrm{MS}$ \\
\hline 2113 & 2 & Cumin alcohol & 0.2 & $\mathrm{tR}, \mathrm{MS}$ \\
\hline 2144 & 4 & Spathulenol & 0.2 & MS \\
\hline 2198 & 2 & Thymol & 0.3 & $\mathrm{tR}, \mathrm{MS}$ \\
\hline 2239 & 2 & Carvacrol & 39.3 & $t R, M S$ \\
\hline \multirow[t]{7}{*}{2392} & 4 & $\begin{array}{l}\text { Caryophylla-2(12),6-dien-5 } \beta \text {-ol (=Caryophyllenol } \\
\text { II) }\end{array}$ & 0.7 & MS \\
\hline & & Monoterpene Hydrocarbones $(1)^{\mathrm{b}}$ & 36.5 & \\
\hline & & Oxygenated Monoterpenes (2) ${ }^{\mathrm{b}}$ & 49.3 & \\
\hline & & Sesquiterpene Hydrocarbones (3) b & 4.6 & \\
\hline & & Oxygenated Sesquiterpenes (4) b & 3.4 & \\
\hline & & Others (5) b & 1.3 & \\
\hline & & Total & 95.1 & \\
\hline
\end{tabular}

a RRI: Relative retention indices calculated against $n$-alkanes;

b Main group code

c \%: calculated from FID data

d IM: Identification Method; $\mathrm{tR}$, identification based on the retention times (tR) of genuine standard compounds on the HP Innowax column; MS, tentatively identified on the basis of computer matching of the mass spectra with those of the Wiley and MassFinder libraries and comparison with literature data.

e tr: Trace $(<0.1 \%)$ 

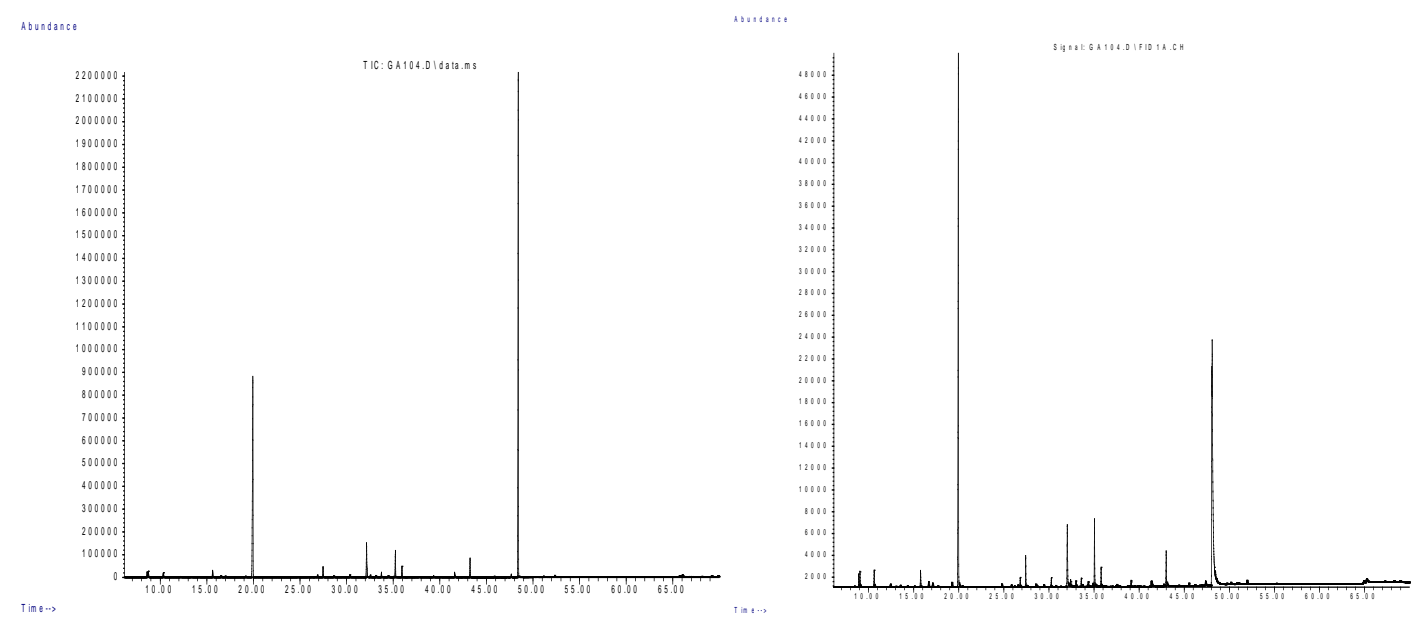

Figure 1. GC/MS and GC/FID chromatograms of the oil.

For the first time here antimicrobial properties of the O. boissieri essential oil and herbal methanol extract were studied in comparison with the standard agents. Antimicrobial effects of the OEo, carcavrol, $p$ cymene and total methanol extract were screened against five Gram (+), five Gram (-) bacteria and five strains of pathogenic Candida with the standard antimicrobial agent simultaneously (Table 2). The oil showed inhibition on the growth of tested bacteria between the concentrations of 31.25 to $1000 \mu \mathrm{g} / \mathrm{mL}$.

Remarkably, known as a skin pathogen Staphylococcus epidermidis was inhibited by the oil having a MIC value of $31.25 \mu \mathrm{g} / \mathrm{mL}$. All tested bacteria were inhibited by the carvacrol similar MIC values with OEo. However, oil was found more active against S. aureus, L. monocytogenes and S. epidermidis when compared with pure carvacrol, which may support synergistic contributions of other terpenoids in the oil. Other main compound $p$-cymene was showed weak effects against all tested bacteria species $(4000-16.000 \mu \mathrm{g} / \mathrm{mL})$. Except for S. epidermidis, methanol extract was stopped the growth of tested bacteria having MIC values of 1000 and $2000 \mu \mathrm{g} / \mathrm{mL}$. According to antibacterial results (Table II) all Gram (+) bacteria were more susceptible to OEo and carvacrol.

Table 2. Minimum inhibitory concentrations of samples (MIC, $\mu \mathrm{g} / \mathrm{mL}$ ).

\begin{tabular}{|c|c|c|c|c|c|c|c|c|}
\hline Bacteria strains & & Gram & OEo $^{a}$ & $C^{b}$ & $P^{c}$ & MEd $^{d}$ & St-1e & St-2 \\
\hline B. cereus & NRRL B-3711 & + & 62.5 & 62.5 & 4000 & 1000 & 0.125 & 8 \\
\hline B. subtilis & NRRL B-4378 & + & 62.5 & 62.5 & 4000 & 1000 & 0.25 & 2 \\
\hline S. marcescens & NRRL B-2544 & - & 1000 & 250 & 8000 & 2000 & 1 & 1 \\
\hline E. coli & ATCC 8739 & - & 1000 & 125 & 8000 & 1000 & 2 & 2 \\
\hline S. typhimurium & ATCC 14028 & - & 1000 & 125 & 16000 & 1000 & 1 & 2 \\
\hline S. aureus & ATCC 43300 & + & 62.5 & 125 & 4000 & 1000 & 0.125 & 2 \\
\hline E. coli O157:H7 & RSSK 234 & - & 500 & 250 & 8000 & 1000 & 2 & 2 \\
\hline P. aeruginosa & ATCC 10145 & - & 1000 & 500 & 8000 & 1000 & 16 & 32 \\
\hline L. monocytogenes & ATCC 19111 & + & 62.5 & 125 & 4000 & 1000 & 0.125 & 2 \\
\hline S. epidermidis & ATCC 14990 & + & 31.25 & 125 & 4000 & 250 & 0.25 & 2 \\
\hline Candida strains & & & & & & & St-3 & St-4 \\
\hline Candida albicans & ATCC 10231 & naf $^{f}$ & 125 & 125 & 500 & 1000 & 0.25 & 0.25 \\
\hline C. utilis & NRRL Y-900 & na & 125 & 250 & 250 & 250 & 0.5 & 0.5 \\
\hline C. tropicalis & ATCC 1369 & na & 250 & 250 & 250 & 1000 & 0.25 & 0.25 \\
\hline C. albicans & ATCC 24433 & na & 250 & 125 & 250 & 1000 & 0.5 & 0.25 \\
\hline C. parapsilosis & ATCC 22019 & na & 125 & 250 & 1000 & 250 & 0.25 & 0.25 \\
\hline $\begin{array}{l}\text { a OEo: Origanum bo } \\
\text { b C: Carvacrol } \\
\text { c PC: } p \text {-Cymene } \\
\text { d ME: Methanol ext } \\
\text { e St-1: Ampicillin, S } \\
\text { f na: Not applicable }\end{array}$ & Chloramphenic & $\mathrm{An}$ & 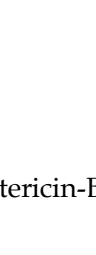 & & ble & & & \\
\hline
\end{tabular}


Similar to our results, previous studies support our findings that the phenolic monoterpenes are more effective against Gram (+) cell wall rather than sophisticated Gram (-) wall [20, 36, 37]. The most susceptible S. epidermidis chosen for bioautography assay as a test bacterium. Thanks to bioautography assay, bioactive component of the oil was determined undoubtedly as carvacrol because of the uncoloured inhibition zones on the TLC plate after overnight incubation (Figure 2).

It is well known that, as a phenolic monoterpene carvacrol possess strong inhibition effects against several pathogenic microorganisms [18-20, 24, 36]. All tested samples were exhibited moderate to weak anticandidal effects in comparison with Ketokonazol and Amphotericin-B, in the range of 125 to $1000 \mu \mathrm{g} / \mathrm{mL}$ (MIC). Souza et al. (2010) found that the essential oil from Origanum vulgare and O. majorana showed inhibition of the growth of C. albicans, C. crusei and C. tropicalis cells between the concentration of 80 to $160 \mu \mathrm{L} / \mathrm{mL}$ similar to our results [38].

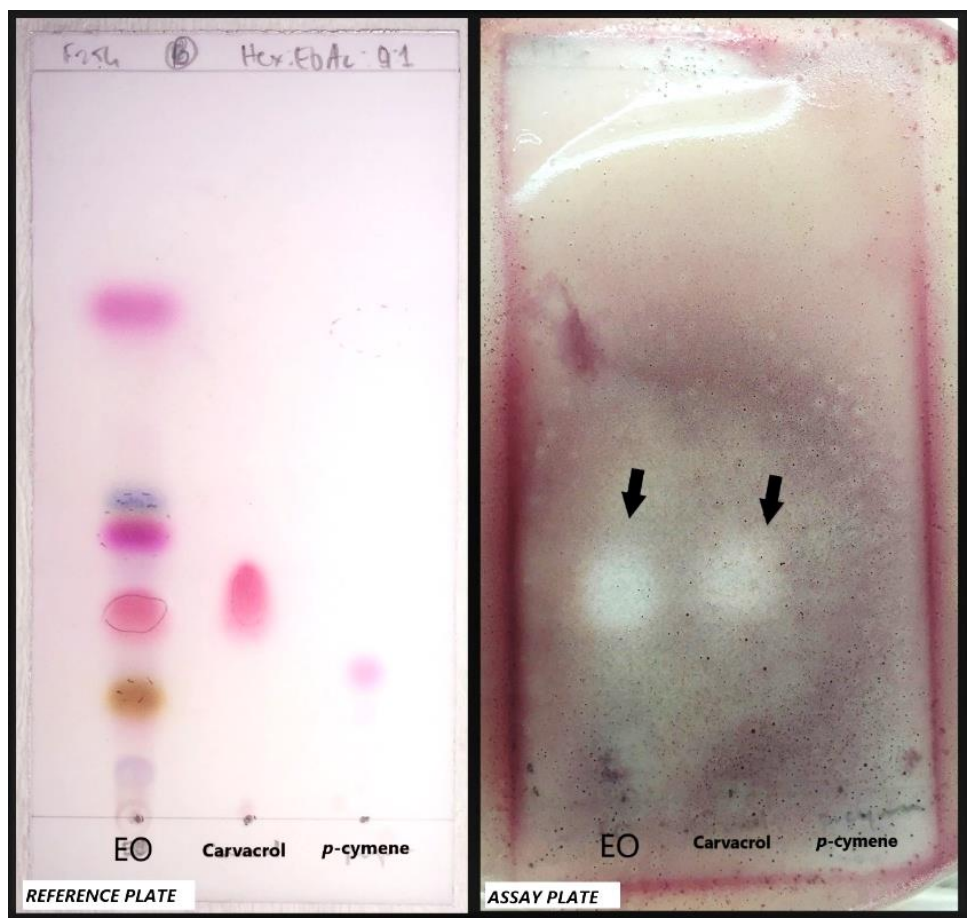

Figure 2. TLC-Bioautography assay result

\section{CONCLUSION}

According to all activity results, $\mathrm{O}$. boissieri essential oil showed strong antibacterial effects against tested bacteria panel especially Gram positives, while it was displayed moderate effects against Candida. Carvacrol was found bioactive component of the oil according to TLC-bioautographic assay. TLCbioautographic assay is useful tool for detection of the bioactive components of essential oils. O. boissieri oil has promising antibacterial natural product for dermal pathogen S. epidermidis.

\section{MATERIALS AND METHODS}

\subsection{Plant material and extraction process}

Plant material was collected from Namrun Province, İçel, Turkey in June, 2016. The plant specimens were authenticated and voucher specimen is kept at the Herbarium of Anadolu University, Faculty of Pharmacy (ESSE No:15490). Shade-dried aerial parts (50 g) of the plant were hydrodistilled for $3 \mathrm{~h}$ using a Clevenger-type apparatus to yield $2.0 \%$ of the oil. The essential oil was dried over anhydrous sodium sulphate and stored at $+4^{\circ} \mathrm{C}$ in amber vial for further analysis.

To obtain crude methanol extract, air dried plant samples were chopped into small pieces and used brass mortar to pound a coarse powder. Plant material extracted with methanol by using orbital shaker at 150 rpm for $24 \mathrm{~h}$. The extract was filtered through a standard filter paper and concentrated using a rotary evaporator with the water bath $\left(40^{\circ} \mathrm{C}\right)$. The dry residue was kept at $4^{\circ} \mathrm{C}$ until antimicrobial assay. 


\subsection{Gas chromatography mass spectrometry (GC/MS) analysis}

The GC/MS analysis was carried out with an Agilent 5975 GC-MSD system. 60 m Innowax FSC column ( $0.25 \mathrm{~mm}$ inner diameter., $0.25 \mu \mathrm{m}$ film thickness) was used with helium as carrier gas $(0.8 \mathrm{ml} / \mathrm{min})$. GC oven temperature was set at $60^{\circ} \mathrm{C}$ for $10 \mathrm{~min}$ and programmed to $220^{\circ} \mathrm{C}$ at a rate of $4^{\circ} \mathrm{C} / \mathrm{min}$, and kept constant at $220^{\circ} \mathrm{C}$ for $10 \mathrm{~min}$ and then programmed to $240^{\circ} \mathrm{C}$ at a rate of $1^{\circ} \mathrm{C} / \mathrm{min}$. Split ratio was adjusted at $40: 1$. The injector temperature was set at $250^{\circ} \mathrm{C}$. Mass spectra were recorded at $70 \mathrm{eV}$. Mass range was from $\mathrm{m} / \mathrm{z} 35$ to 450 .

\subsection{Gas chromatography (GC) analysis}

The GC analysis was carried out using an Agilent 6890N GC system. FID detector temperature was $300^{\circ} \mathrm{C}$. To obtain the same elution order with GC-MS, simultaneous auto-injection was done on a duplicate of the same column applying the same operational conditions. Relative percentage amounts of the separated compounds were calculated from FID chromatograms. The analysis results are given in Table 1. Identification of the essential oil components were carried out by comparison of their relative retention times with those of authentic samples or by comparison of their relative retention index (RRI) to series of n-alkanes. Computer matching against commercial (Wiley GC/MS Library, MassFinder 3 Library) [28, 29] and in-house "Başer Library of Essential Oil Constituents" built up by genuine compounds and components of known oils, as well as MS literature data [30,31] was used for the identification.

\subsection{Microorganisms}

Standard strains of Bacillus cereus NRRL B-3711, Bacillus subtilis NRRL B-4378, Serratia marcescens NRRL B-2544, E. coli ATCC 8739, Salmonella typhimurium ATCC 14028, Staphylococcus aureus ATCC 43300, E. coli O157:H7 RSSK 234, Pseudomonas aeruginosa ATCC 10145, Listeria monocytogenes ATCC 19111, Staphylococcus epidermidis ATCC 14990, Candida albicans, ATCC 10231, Candida utilis NRRL Y-900, Candida tropicalis ATCC 1369, Candida albicans ATCC 24433 and Candida parapsilosis ATCC 22019 were used as microorganism test panel.

\subsection{Antimicrobial assay}

Antibacterial and anticandidal properties of methanol extract, essential oil and its major compounds carvacrol (Aldrich) and p-cymene (Aldrich) were tested by using slightly modified CLSI protocols M7-A7 and M27-A2 [32, 33]. Five Candida strains that cause invasive fungal infections and ten different pathogenic bacteria strains were used as test microorganisms. Unlike the standard CLSI protocols, test solutions of the essential oil, authentic compounds and the extract were prepared between the concentration range of 16.0 to 0.015 $\mathrm{mg} / \mathrm{mL}$. Serial two fold dilutions of the samples were made on 96-well microtitration plates. Standard antimicrobial agents were diluted according the CLSI protocols. Amphotericin-B (Sigma-Aldrich) and Ketoconazol (Sigma-Aldrich) were used as standard antifungal agents where chloramphenicol (SigmaAldrich) and ampicillin (Sigma-Aldrich) were used as antibacterial agents. Candida parapsilosis ATCC 22019 was used for quality control strain for the protocol named M27-A2 susceptibility testing of yeasts.

\subsection{TLC bioautography assay}

According to antimicrobial assay results, OEo were subjected to Bioautography assay for the determination of active compounds in the oil. For this purpose, precoated silica gel $60_{\mathrm{F} 254}$ aluminium plates $(\sim 0.2 \mathrm{~mm}$, Merck) were used $(50 \times 100 \mathrm{~mm}) .15 \mu \mathrm{L}$ of OEo, carvacrol and $p$-cymene solutions $(10 \mathrm{mg} / \mathrm{mL}$ in $n$ hexane) were applied using Drummond micro-capillaries onto two equal TLC plates and developed (9:1 v/v, $n$-hexane/ethyl acetate) in the same time.

In one plate, the separated compounds were visualized under UV light (365 and $254 \mathrm{~nm}$ ) and sprayed with anisaldehyde $/ \mathrm{H}_{2} \mathrm{SO}_{4}$ reagent followed by heating to $110^{\circ} \mathrm{C}$. The other plate was used for the bioautography assay, to determine the separated bioactive compounds. Overnight culture of liquid Mueller Hinton Broth with S. epidermidis ATCC 14990 were adjusted to McFarland No.05 turbidity standard (approximately $10^{8} \mathrm{CFU} / \mathrm{mL}$ ). Additionally, $9 \mathrm{~mL}$ sterilized Mueller Hinton Broth in addition of agar (7.5\%) was used as molten agar and kept at $45 \pm 1^{\circ} \mathrm{C}$ water bath. $1 \mathrm{~mL}$ of the liquid culture solution was added into the Molten Agar and vortexed for 15 seconds. Finally, the inoculated medium was poured onto the TLC plate and incubated at $37^{\circ} \mathrm{C}$ for $24 \mathrm{~h}$. The plate was sprayed using a $1 \%(\mathrm{w} / \mathrm{v}, \mathrm{EtOH})$ tetrazolium violet reagent $(2,5-$ diphenyl-3 [a-naphthyl] tetrazolium chloride, Sigma) and incubated at $37^{\circ} \mathrm{C}$ for further $4 \mathrm{~h}$. After incubation, inhibition zones were visualized against the coloured background oil [34, 35]. 
Author contributions: Concept - G.İ., B.D., Y.B.K.; Design - G.İ.; Supervision - G.İ;; Materials - G.İ., Y.B.K.; Data Collection and Processing - G.I., B.D.; Analysis and/or Interpretation - G.İ., B.D.; Literature Search - G.İ., Y.B.K.; Writing - G.İ., B.D., Y.B.K.; Critical Reviews - G.İ., B.D., Y.B.K.

Conflict of interest statement: The authors declared no conflict of interest.

\section{REFERENCES}

[1] Ietswaart JH. A Taxonomic Revision of the Genus Origanum (Labiatae). Leiden Botanical Series 4. Leiden University Press, The Hague, The Netherlands 1980

[2] Kokkini S. Taxonomy, diversity and distribution of Origanum species, In: Padulosi S. (Ed.). Oregano. 14th Proceedings of the IPGRI International Workshop on Oregano, 8-12 May 1996, CIHEAM, Valenzano (Bari), 1996. pp.2-12.

[3] Sadıkoğlu N, Özhatay N. Morphological characteristics of exported taxa as Oregano from Turkey I: Origanum. J Faculty Pharm Istanbul Univ. 2015; 45(2): 87-126.

[4] Başer KHC. The Turkish Origanum species. In: Kintzios E. (Ed.) Oregano: The genera Origanum and Lippia. Taylor \& Francis; London, 2002, pp.109-126.

[5] Başer KHC, Özek T, Tümen G, Sezik, E. Composition of the essential oils of Turkish Origanum species with commercial importance. J Essent Oil Res. 1993; 5: 619-623. [CrossRef]

[6] Baricevic D, Bartol T. The biological/pharmacological activity of the Origanum genus. In: Kintzios E. (Ed.) Oregano: the genera Origanum and Lippia. Taylor and Francis, London, 2002, pp.177-214.

[7] Şahin F, Güllüce M., Daferera D, Sökmen A, Sökmen M, Polissiou M, Agar G, Özer H. Biological activities of the essential oils and methanol extract of Origanum vulgare ssp. vulgare in the Eastern Anatolia region of Turkey. Food Control, 2004; 15(7): 549-557. [CrossRef]

[8] Chishti S, Kaloo ZA, Sultan P. Medicinal importance of genus Origanum: A review. J Pharmacognosy Phytother. 2013; 5(10): 170-177.

[9] Ličina BZ, Stefanović OD, Vasić SM, Radojević ID, Dekić MS, Čomić LR. Biological activities of the extracts from wild growing Origanum vulgare L. Food Control. 2013; 33(2): 498-504. [CrossRef]

[10] Han X, Parker TL. Anti-inflammatory, tissue remodeling, immunomodulatory, and anticancer activities of oregano (Origanum vulgare) essential oil in a human skin disease model. Biochimie Open. 2017; 4: 73-77. [CrossRef]

[11] Elshafie HS, Armentano MF, Carmosino M, Bufo SA, De Feo V, Camele I. Cytotoxic activity of Origanum vulgare L. on hepatocellular carcinoma cell line HepG2 and evaluation of its biological activity. Molecules. 2017; 22(9): 1435. [CrossRef]

[12] Adam K, Sivropoulou A, Kokkini S, Lanaras T, Arsenakis M. Antifungal activities of Origanum vulgare subsp. hirtum, Mentha spicata, Lavandula angustifolia, and Salvia fruticosa essential oils against human pathogenic fungi. J Agric Food Chem. 1998; 46(5): 1739-1745. [CrossRef]

[13] Bakkali F, Averbeck S, Averbeck D, Idaomar M. Biological effects of essential oils-a review. Food Chem Toxicol. 2008; 46(2): 446-475. [CrossRef]

[14] Soković M, Glamočlija J, Marin PD, Brkić D, van Griensven LJ. Antibacterial effects of the essential oils of commonly consumed medicinal herbs using an in vitro model. Molecules. 2010; 15(11): 7532-7546. [CrossRef]

[15] Leyva-López N, Gutiérrez-Grijalva EP, Vazquez-Olivo G, Heredia JB. Essential oils of oregano: Biological activity beyond their antimicrobial properties. Molecules. 2017; 22(6): 989. [CrossRef]

[16] Lambert RJ, Skandamis PN, Coote PJ, Nychas GJ. A study of the minimum inhibitory concentration and mode of action of oregano essential oil, thymol and carvacrol, J Appl Microbiol. 2001; 91: 453-462. [CrossRef]

[17] Nostro A, Blanco AR, Cannatelli MA, Enea V, Flamini G, Morelli I, Sudano RA, Alonzo V. Susceptibility of methicillin-resistant Staphylococci to oregano essential oil, carvacrol and thymol. FEMS Micro Lett. 2004; 230: 191-195. [CrossRef]

[18] Nostro A, Roccaro SA, Bisignano G, Marino A, Cannatelli MA, Pizzimenti FC, Cioni PL, Procopio F, Blanco AR. Effects of oregano, carvacrol and thymol on Staphylococcus aureus and Staphylococcus epidermidis biofilms. J Med Microbiol. 2007; (56)4: 519-523. [CrossRef]

[19] Kotan R, Kordali S, Çakır A. Screening of antibacterial activities of twenty-one oxygenated monoterpenes. Z Naturforsch C. 2007; 62(7-8): 507-513. [CrossRef] 
[20] Xu J, Zhou F, Ji BP, Pei RS, Xu N. The antibacterial mechanism of carvacrol and thymol against Escherichia coli. Letters App Microbiol. 2008; 47, 174-179. [CrossRef]

[21] Carson CF, Hammer KA. Chemistry and Bioactivity of Essential Oils, In: Thormar H. (Ed.) Lipids and Essential Oils as Antimicrobial Agents. John Wiley \& Sons, Ltd., New York, 2011. pp.203-238.

[22] De Martino L, De Feo V, Fratianni F, Nazzaro F. Chemistry, antioxidant, antibacterial and antifungal activities of volatile oils and their components. Nat Prod Commun. 2009; 4 :1741-1746. [CrossRef]

[23] Du E, Gan L, Li Z, Wang W, Liu D, Guo Y. In vitro antibacterial activity of thymol and carvacrol and their effects on broiler chickens challenged with Clostridium perfringens. J Anim Sci Biotechnol. 2015; 6: 58. [CrossRef]

[24] Khan ST, Khan M, Ahmad J, Wahab R, Abd-Elkader OH., Musarrat J, Alkhathlan HZ, Al-Kedhairy AA. Thymol and carvacrol induce autolysis, stress, growth inhibition and reduce the biofilm formation by Streptococcus mutans. AMB Express. 2017; 7(1): 49. [CrossRef]

[25] Edris AE. Pharmaceutical and therapeutic potentials of essential oils and their individual volatile constituents: A review. Phytother Res. 2007; 21: 308-323. [CrossRef]

[26] Ietswaart JH. Origanum L. In: Davis PH. (Ed.). Vol. 7 Flora of Turkey and the East Aegean Islands: Edinburgh Univ. Press, Edinburgh, 1982, pp.299.

[27] Başer KHC, Duman H. Composition of the Essential Oils of Origanum boissieri letswaart and O. bargyli Mouterde. J Essent Oil Res. 1998; 10: 71-72. [CrossRef]

[28] McLafferty FW, Stauffer DB. The Wiley/NBS Registry of Mass Spectral Data, J Wiley and Sons, New York, pp.1989.

[29] Koenig WA, Joulain D, Hochmuth DH. Terpenoids and Related Constituents of Essential Oils. MassFinder 3, Hamburg, Germany, 2004.

[30] Joulain D, Koenig WA. The Atlas of Spectra Data of Sesquiterpene Hydrocarbons, EB-Verlag, Hamburg, 1998, pp.10658.

[31] ESO 2000. (The Complete Database of Essential Oils) program, https://www.leffingwell.com/virtual_xp_mode.htm (accessed on 12 June 2017).

[32] National Committee for Clinical Laboratory Standards. Reference method for broth dilution antifungal susceptibility testing of yeasts. Approved Standard-M27A2. CLSI, Wayne PA, USA. 2002.

[33] National Committee for Clinical Laboratory Standards. Methods for Dilution Antimicrobial Susceptibility Tests for Bacteria That Grow Aerobically. Approved Standard-M7A7. Wayne PA, USA. 2006.

[34] Rahalison L, Hamburger M, Hostettmann K, Monod M, Frenk EA, Bioautographic agar overlay method for the detection of antifungal compounds from higher plants. Phytochem Anal. 1991; 2: 199-203. [CrossRef]

[35] Hostettmann K. Strategy for the biological evaluation of plant extracts. Pure App Chem. 1999; 70: 1109-1113.

[36] İşcan G. Antibacterial and anticandidal activities of common essential oil constituents. Rec Nat Prod. 2017; 11(4): 374388. [CrossRef]

[37] Nazzaro F, Fratianni F, De Martino L, Coppola R, De Feo V. Effect of essential oils on pathogenic bacteria. Pharmaceuticals (Basel). 2013; 6: 1451-1474. [CrossRef]

[38] Souza NAB, Lima EDO, Guedes DN, Pereira, FDO, Souza ELD, Sousa FBD. Efficacy of Origanum essential oils for inhibition of potentially pathogenic fungi. Braz J Pharm Sci. 2010; 46(3): 499-508. [CrossRef] 